Article

\title{
Patterns of Legitimation in Hybrid Transnational Regimes: The Controversy Surrounding the Lex Sportiva
}

\author{
Klaus Dieter Wolf \\ Peace Research Institute Frankfurt, 60329 Frankfurt am Main, Germany; E-Mail: kdwolf@t-online.de
}

Submitted: 6 December 2016 | Accepted: 9 January 2017 | Published: 15 March 2017

\begin{abstract}
This article addresses concerns that the growth in global governance may be bringing with it a decline in the significance of democratic sources of political legitimacy. One approach in evaluating such concerns is to ask whether the respective patterns of legitimation for private and public authority differ or whether they refer to a similar set of normative standards. Private transnational governance regimes provide useful contexts in which to assess the presumed democratic erosion. They seem, almost of themselves, to make the case for such a decline: in them regulatory authority is exercised by nonstate actors who, by their very nature, lack the kind of authorization afforded by the democratic procedures that legitimize state-based regulation; in addition, they are intrinsically linked to the notion of politics as a form of problem-solving rather than as the exercise of power. Given these characteristics, when governance arrangements of this kind are subjected to criticism, one would expect justificatory responses to relate primarily to performance, with normative criteria such as fundamental individual rights and the imperative for democratic procedure playing only a minor role. On the basis of a qualitative content analysis, the study tests three ideal-type patterns of legitimation for plausibility. The case selected for examination is the recent controversy surrounding the hybrid governance regime that operates to prevent the use of performance-enhancing drugs in sport. The debate offers the possibility of a 'nutshell' comparison of the respective patterns of legitimation used in criticizing and justifying state and non-state regulatory authority. This comparison yields two findings. The first is that the values used to appraise the state-based components of the sporting world's hybrid regulatory regime do not differ systematically from those used to appraise the private elements: contestation and justification in both cases are founded on normative criteria relating to fundamental individual rights and democratic procedure and not just on performance-related considerations. The second finding is that justificatory grounds of the first type do not appear to be diminishing in importance vis-à-vis those of the second.
\end{abstract}

\section{Keywords}

global governance; hybrid transnational regimes; legitimacy patterns; public-private authority

\section{Issue}

This article is part of the issue "Legitimization of Private and Public Regulation: Past and Present", edited by Klaus Dieter Wolf (Peace Research Institute Frankfurt, Germany), Peter Collin (Max Planck Institute for European Legal History, Germany) and Melanie Coni-Zimmer (Peace Research Institute Frankfurt, Germany).

(C) 2017 by the author; licensee Cogitatio (Lisbon, Portugal). This article is licensed under a Creative Commons Attribution 4.0 International License (CC BY).

\section{Introduction}

Global governance is characterized by the increasing exercise of regulatory authority by private actors. These actors participate directly in the formulation and implementation of rules governing international affairs (see Cutler, Haufler, \& Porter, 1999; Hall \& Biersteker, 2002; Wolf, 2008). This omnipresent regulatory plurality is a challenge for anyone attempting to assess the legitimacy of authority beyond the state (Wolf, 2006). One of its effects is to put state actors' traditional legitimatory repertoires under pressure and concerns have begun to be expressed that the rise in governance beyond the state may be bringing with it a decline in the significance of democratic sources of political legitimacy (Papadopoulos, 2010; Zuern, 2011). The present article explores 
these concerns, specifically by asking whether the emergence of private forms of regulation in the transnational sphere has been accompanied by a shift in the normative standards by which the legitimacy of regulatory authority is judged, or whether, instead, the respective ways in which private and state-based regulation are legitimized are grounded in similar values. ${ }^{1}$

Transnational private governance regimes are useful contexts in which to assess the presumed decline of democratic sources of legitimation in the trans-state realm. They seem, almost of themselves, to make the case for such a decline: in them regulatory authority is exercised by non-state actors who, by their very nature, lack the kind of authorization afforded by the democratic procedures that legitimize state-based regulation; in addition, they are intrinsically linked to the notion of politics as a means of problem-solving rather than as the (democratically controlled) exercise of power. Given these characteristics, when governance arrangements of this kind are subject to criticism, one would expect justificatory responses to relate primarily to performance, with normative criteria such as fundamental individual rights and the imperative for democratic procedure playing only a minor role.

There is a wealth of literature listing the normative criteria that transnational private self-regulatory regimes should adhere to and then working out, through case studies, how far they actually do so. ${ }^{2}$ By contrast, relatively little is known about which of these normative criteria assume actuality in real-life controversies about the legitimacy of the regulatory authority exercised by private actors. By including participant perspectives on what is legitimate and why, we will have a more comprehensive picture on which to base any assessment of the decline in significance which democratic legitimation of regulatory authority has allegedly undergone with the rise in private regulation.

The present investigation begins by identifying three ideal-type arguments regarding the legitimatory demands associated with private self-regulation. These are extracted from the relevant literature and represent three distinct patterns of legitimation (Section 2). From this theoretical material, a set of keywords is derived to serve as a guide for content analysis of actual controversies relating to the legitimacy of regulatory authority. Section 3 outlines the particular case selected to test the plausibility of the theoretical conjectures and identifies the data-sources used for the empirical analysis. The case selected for a comparison of the respective grounds on which the state-based and private selfregulatory elements of this regime are legitimized or criticized is that of the hybrid governance regime that oper- ates to prevent the use of performance-enhancing drugs in sport. 'The crisis of confidence in the governance of sport', remarked one athletes' representative recently, 'has justifiably reached new levels' (Schwab, 2015). It is a crisis reflected in widespread debate about the lack of legitimacy of transnational private self-regulation and the need for state involvement to make up for this. Focusing on the example of recent national anti-doping legislation in Germany-introduced in response to the presumed shortcomings of existing transnational private arrangements-Section 4 offers a qualitative content analysis of a case that is particularly apt to our purpose since it allows the pros and cons of state-based and non-state regulation to be compared, as it were, 'in a nutshell'.

The study yields two key findings. The first is that the value patterns used to appraise the state-based components of the sporting world's hybrid regulatory regime do not differ systematically from those used to appraise the private elements: in both cases contestation ${ }^{3}$ and justification are founded on normative criteria relating to fundamental individual rights and democratic procedure as well as on performance-related considerations. The second finding is that justificatory grounds of the first type do not appear to be diminishing in importance vis-à-vis those of the second.

\section{Approaches to the Legitimation of Private Self-Regulation}

The ideal-type arguments described here are drawn from different strands of the literature on the legitimation of private self-regulation. On the basis of these arguments, categories are identified which are then used to structure the empirical analysis relating to potential differences in patterns of legitimation for public and private authority.

\subsection{Private Regulatory Authority Neither Needs nor Is Amenable to Democratic Legitimation}

This first approach, although it has a long history as a fundamental principle of political liberalism in the Tocquevillean tradition (Gutmann, 1998), tends-undeservedly, given its heuristic value-to fall victim to dichotomized debates as to whether output or input requirements take precedence when it comes to legitimacy. ${ }^{4}$ It casts doubt on the notion that private self-regulation requires any further legitimation at all, given its prior justification in freedom of association. Associational freedom safeguards a person's right to join a group and to take collective action in pursuance of the interests of that group.

\footnotetext{
${ }^{1}$ Bernstein (2011) poses a similar question.

2 See, among many others, Cashore (2002), Wolf (2002), Keohane and Nye (2003), Pattberg (2005), Boerzel and Risse (2005), Held and Koenig-Archibugi (2005), Bernstein and Cashore (2007), Dingwerth (2007), Flohr, Rieth, Schwindenhammer and Wolf (2010), Scholte (2011), and Bodansky (2013).

${ }^{3}$ Contestation is here taken to mean a questioning of the grounds on which certain regulatory arrangements claim legitimacy. For an excellent overview of the literature on norm contestation in general, see Wolff and Zimmermann (2016).

4 'Output' and 'input' here refer respectively to acceptance created by effective problem-solving that serves the public interest and acceptance created by democratic procedures (see Scharpf, 1999).
} 
As a constitutionally enshrined expression of civil liberty, this fundamental right is founded on each individual's capacity for self-determination and self-governance and has no need to justify itself further. In particular, it has no need to demonstrate the democratic legitimacy of the internal structures and decision-making processes through which it is exercised. On the contrary, as long as it does not violate the law, it is entitled to look to the state, in its capacity as a guarantor, to ensure its protection (Schiedermair, 2012).

To quote corroborative voices from another quarter: legal scholars assert that private norm-setting that takes place within the framework of voluntary selfcommitment falls below the threshold of the kind of legislative and executive power exercised by a state (see Michael, 2005, pp. 434-435). Consequently-and in contrast to the position with collectively binding decisionmaking that follows from the mandatory exercise of sovereign authority-private authority is exempted from any requirement to justify itself, just so long as there continues to be scope for regulatory influence by the state or a community of states (Abbott \& Snidal, 2009; Wolf, 2014, p. 287). According to this ideal-type argument, any legitimacy-related dispute about transnational private self-regulatory regimes will concern not the performance or internal democratic structure of the regime but the justification for any state interference with civil liberty.

\subsection{Private Regulatory Authority Must Meet Output-Related Criteria for Legitimacy}

In this second line of reasoning, the premise of a decline in democratic legitimation when regulatory authority is transferred to private actors can be traced back to a shift of focus in political science towards policy research, new modes of governance, and new forms of public management (Héritier, 2002; Pierre, 2000; Pollitt \& Bouckaert, 2000; see also Krahmann, 2017). The perception that there is a crisis in the regulatory state in general and that 'traditional public command-and-control' in particular has its limitations as a means of governance (Kooiman, 2000, p. 139) has shifted output-related normative considerations centre-stage. The thinking here is that governments, keen to enhance their capacity to provide common goods, have pinned their hopes on achieving the 'modernization' of state and society by directly involving former addressees of public regulation in the governance process (Mayntz, 2002). This move, it is argued, has not been motivated primarily by a democratic concern to increase participation; rather it is driven by the idea that problem-solving effectiveness can be enhanced by utilizing hitherto untapped resources. The growth in private-governance involvement in both the domestic and transnational sphere is thus intrinsically linked to a notion of politics as a form of problem-solving rather than as the exercise of power (Benz \& Papadopoulos, 2006, p. 7; Ronit \& Schneider, 2000). As potential partners in governance, private regulators need to be invested with epistemic authority that draws on expertise and problemsolving capacity as sources of legitimation (see Simmerl \& Zuern, 2016; Zagzebski, 2012). This line of argument would lead one to expect that controversies about privategovernance involvement-at both domestic and transnational level-will be primarily performance-related and that democratically rooted requirements in regard to legitimacy will continue to figure only in relation to the political authority exercised by states.

\subsection{Private Regulatory Authority Must Meet Input-Related Criteria for Legitimacy}

The third ideal-type argument asserts that the fundamental division between public power and private freedom' which forms the basis of the first argument 'cannot be maintained in the case of private standardsetters who utilize a putative freedom to exercise power' (Michael, 2005, p. 44). This view also extends beyond the second argument, in which self-regulation is seen not as the exercise of power but as a contribution to the provision of common goods. This extended perspective on the 'democratic deficits' of transnational private self-regulation is the subject of a burgeoning body of literature $e^{5}$ and the requirements to which it gives rise are reflected in the design of many transnational selfregulatory arrangements - the Forest Stewardship Council often being cited as an example (see, among many others, Pattberg, 2005, 2006). One of the key observations of the 'politicization' hypothesis (Zuern, 2014; Zuern, Binder, \& Ecker-Ehrhardt, 2012) is that international institutions are increasingly being criticized for not matching their 'new, authority-generating quality' (Zuern, 2012, p. 409)-backed up by coercive compliance-mechanisms and often at odds with state-based regulatory activitieswith appropriate levels of accountability. Although the politicization hypothesis was originally formulated with reference to intergovernmental institutions and the changes occurring in these, it is equally applicable to private transnational self-regulatory regimes, which often assume quasi-state regulatory authority-including legislative, executive, and judicial functions. If the politicization mooted by Zuern and others has been matched by an increasing insistence on input-related standards for the justification of private contributions to transnational governance, then the proliferation of transnational private regulatory authority need not necessarily result in a diminution in the significance of democratic sources of legitimacy.

\section{The Lex Sportiva: Case Selection and Data Sources}

\subsection{Case Selection}

The case selected as the basis for probing the plausibility of these theoretical positions is that of sports law-lex

\footnotetext{
${ }^{5}$ See, among others, Cashore (2002), Bernstein and Cashore (2007), Dingwerth (2007) and Flohr et al. (2010).
} 
sportiva-more precisely, the transnational regulatory regime that operates to prevent the use of performanceenhancing substances in sport. So-called 'doping' is one of the major regulatory problems facing the world of sports. ${ }^{6}$ In 1999, in an attempt to tackle this issue, the World Anti-Doping Agency (WADA) was set up. Its World Anti-Doping Code (WADC) represents a self-regulatory attempt by sports organizations to co-ordinate anti-doping measures worldwide. The Code is founded on regulatory authority exercised by private actors operating in nonstate institutions. The first version of it came into force in 2004; the second, fully revised version has been effective since January 2015 (WADA, 2014).

The core, standardized component of this regime is essentially private in nature. Supplementing it is a fragmented, unsystematized public component consisting of: a variety of national anti-doping laws; two intergovernmental conventions (the Anti-Doping Convention of the Council of Europe and UNESCO's International Convention against Doping in Sport); and one international declaration (the Copenhagen Declaration on AntiDoping in Sport). In its Anti-Doping Convention, dating from as far back as 1989, the Council of Europe declared that 'public authorities and the voluntary sports organisations have complementary responsibilities to combat doping in sport' (Council of Europe, 1989). The document thus acts as a 'big stick' in the background, ensuring public 'shadowing' of sporting self-regulation and, at least indirectly, threatening the imposition of regulatory measures by the state where private arrangements fail (Art. 10, Anti-Doping Convention of the Council of Europe).

The WADC was first recognized by the world of states in the Copenhagen Declaration on Anti-Doping in Sport, which was adopted in 2003 and was subsequently ratified by virtually every state in the world. By means of this declaration, the ratifying states affirmed their commitment to the provisions of the WADC. Sporting organizations that 'are not in compliance with the Code or applicable anti-doping rules adopted pursuant to the Code' (World Conference on Doping in Sport, 2003) lose all or part of their state funding. The second of the conventions mentioned-UNESCO's International Convention against Doping in Sport-was adopted in 2005 (UNESCO, 2005). It is largely based on the version of WADC current at that time, supplementing it with a further commitment by the signatory states to institute suitable legal or other anti-doping measures within their own areas of jurisdiction (Art. 9). With the state parties agreeing to incorporate private standards into international agreements and national legislation, the public 'shadowing' of transnational private regulation was now matched by a remarkable private 'counter-shadowing' of the state (see Héritier \& Lehmkuhl, 2008). ${ }^{7}$ Via the UNESCO Convention and the Copenhagen Declaration, the signatory governments undertake to support the provisions of the privately instituted WADC and bring all other stateinstituted anti-doping measures into line with it.

The lex sportiva is a good candidate for investigation on several counts. Firstly, the transnational selfregulation engaged in by sports organizations is characterized by a particularly high degree of legislative, executive, and judicial authority. Within the autonomous bodies of the sports world, state functions are fulfilled by non-state actors who have the power to lay down binding rules and to impose sanctions where these are violated. Private regulation, bolstered by its anti-doping code, is viewed as the international police-force of highlevel sports; but more than this-it gives the appearance of sitting astride all (sporting) sectors and functioning as a private law-maker and judge. In addition, it seeks to achieve compliance primarily through sanctions and only secondarily through 'softer' forms of governance. Given this broad range of functions, the regulatory authority exercised by private self-regulators in the sports world is amenable to politicization. This means that, at least in principle, this authority is open to contestation and justification by reference to the same norms that are recognized as playing a constitutive legitimating role in the case of mandatory rule-making and rule-enforcement by the state.

Secondly, selection of the lex sportiva for study is based on its general character as a 'regulatory hybrid' (Siekmann, 2012, p. 314). Its overlapping public and private governance arrangements constitute a particularly impressive example of this hybridity. This make-up allows direct, 'in-case' comparison of patterns of legitimation for state and non-state regulation. Thus, the controversy surrounding the German anti-doping legislation that came into force in December 2015 enabled us to view these patterns 'in a nutshell'. Additional anecdotal evidence was drawn from the debates about the limits to sport's capacity for self-healing which were triggered, at about the same time, by the exposure of state-sponsored doping in Russia-and threw a different light on state involvement in the fight against corruption in sport.

\subsection{Data Sources}

The underlying research for this study took the form of a qualitative content analysis of written statements made by political decision-makers and by representatives of both athletes and sports associations. The data was drawn from a variety of textual sources, the core material being culled from records of debates held by the lower chamber of the German parliament (the Bundestag) on 22 May and 13 November 2015 and the rest from records of court and tribunal proceedings, quality national and international newspapers, the sports media, and the websites of political parties and of rele-

\footnotetext{
${ }^{6}$ The brief description given here draws on a more detailed account in Wolf (2014).

7 This shadowing and counter-shadowing emerges particularly clearly in Art. 22 of the WADC ('Involvement of Governments'), which invites governments to commit to the Code by acceding to relevant intergovernmental agreements.
} 
vant national and international sports associations. ${ }^{8}$ The textual data was coded using basic keywords assigned to the three patterns of legitimation outlined above: ${ }^{9}$ (1) freedom of association, autonomy of the societal sphere, self-government, primacy of politics; (2) effectiveness, achievement of regulatory objectives; (3) procedural requirements, protection of basic rights, accountability, rule of law, impartial judicial proceedings. This coding was used to identify patterns of legitimation employed, respectively, for the state and non-state components of the hybrid national-cum-transnational/privatecum-public anti-doping regime. For the sake of userfriendliness, only sample quotations are included within the text; others making essentially the same point appear in the footnotes.

\section{Comparison of Patterns of Legitimation}

The empirical plausibility probe that follows here aims to establish whether the three patterns of legitimation previously outlined are actually used to evaluate the legitimacy of authority and, if so, to what extent. Do the normative criteria by which the state-based components of the sporting world's hybrid regulatory regime differ from those that are invoked in regard to its private elements? More specifically, is it the case that when private authority is being evaluated, justificatory grounds relating to fundamental individual rights and the need for democratic procedure take a back seat?

\subsection{Arguments Relating to Freedom of Association and Autonomy}

\subsubsection{Freedom of Association}

Consistent with the first pattern of legitimation, the large number of statements in favour of self-regulation and against state intervention-from participants in the parliamentary debates, from representatives of sports associations, and in the national and international media-were primarily outward-looking in their references to associational freedom and self-determination. Their chief concern was not performance or the degree to which decision-making processes guaranteed internal self-determination. The underlying premise in all of them was that 'only the Olympic family itself had the right to decide which governance was good and which was bad' (Andersen, 2015). On this view, what legitimates the sporting world's autonomy is freedom of association, which imposes clear limits on state intervention. Thomas Bach, president of the International Olympic Committee (IOC) and a member of the executive board of the Ger- man Olympic Sports Confederation (Deutscher Olympischer Sportbund, DOSB), argued that it was incumbent on politicians to respect this autonomy (Financial Times, 2014). The same sentiment was expressed by the IOC's chief ethics and compliance officer, Girard Zapelli: 'Governments must respect the right of the citizens to work together in associations no matter if the citizens are sports people, coin collectors, environmentalists, rabbit breeders or high school students' (Andersen, 2015). The Olympic Charter was quoted in support of the notion that autonomy is a fundamental principle of sport: 'Recognizing that sport occurs within the framework of society, sports organizations within the Olympic Movement shall have the rights and obligations of autonomy, which include freely establishing and controlling the rules of sport, determining the structure and governance of their organizations, enjoying the right of elections free from any outside influence and the responsibility for ensuring that principles of good governance be applied' (WADA, 2015, p. 71).

State involvement was deemed appropriate only where there was corrupt external interference. Whereas game-manipulation was considered to fall under this head, doping was viewed as an 'internal attack' on the system which, as such, should be dealt with by sport's own sanctions-system (Becker, 2015a). Those drafting criminal law should, it was felt, confine themselves to protecting the basic values of social life. Fairness and integrity in sport did not count as such and were therefore not issues for criminal law. This manifest and wellfounded division must not be meddled with by antidoping legislation (Adolphsen \& Kauerhof, 2013).

\subsubsection{Autonomy}

Sporting autonomy also featured prominently in the opposing arguments-in favour of state-based anti-doping legislation-but the main focus here was on its limits. Although sport, like all other sectors of society, should continue to have its private autonomy and other relevant fundamental rights protected by the state, this did not mean, so it was argued, that sport could operate outside the legal order (Krings, 2015). The advent of commercialization, corruption, and organized crime on the sporting scene, it was felt, had put paid to the notion that any defence of freedom of association in sport was a defence of the freedom of all members of society. The reason the German legislator deemed action impinging on the autonomy of sports federations to be necessary was precisely because it promised to preserve the integrity of this part of the societal sphere, not damage it. In January 2016, co-founder and former president of WADA Richard

\footnotetext{
${ }^{8}$ Specifically: the European Court of Justice (ECJ) and the International Sports Tribunal (CAS), Frankfurter Allgemeine Zeitung, Guardian, Legal Tribune, Los Angeles Times, The National, Neue Zürcher Zeitung, Das Parlament, Der Spiegel, Sports Inquirer, Süddeutsche Zeitung, Tagesspiegel, The Telegraph, Die Welt, Deutschlandfunk, Deutschlandradio, Eurosport, Norddeutscher Rundfunk, German Olympic Sports Confederation, leichtathletik.de, playthegame.org, Spox.com and World Anti-Doping Agency.

${ }^{9}$ In order to allow for comparison with the findings of the other contributions to this issue, we also took account of the common framework suggested by the editors in making our selection (see Coni-Zimmer, Wolf, \& Collin, 2017). In addition to these pre-selected categories, inductive category-development took place during the research process, with additional, more specific terms being included.
} 
W. Pound called the autonomy of sport 'an outdated relic from an earlier era' which had degenerated into 'a shield behind which too many sports organisations at the international and national level have become greenhouses for corruption and crime....This notion of autonomy is not invented so corrupt people can hide behind it' (Andersen, 2015).

As the German minister of the interior Lothar de Maizière put it: 'What we are talking about here is criminal law and federal legislation. Political considerations take priority here, not the autonomy of sport' (Hungermann, 2015). DOSB honorary president Manfred von Richthofen endorsed this view, insisting that: 'If the sporting world asks the state for help in an area where crime is involved, this does not undermine the independence of sport' (Adolphsen \& Kauerhof, 2013). With regard to commercialization, it was argued that the principle of autonomy 'allows for all sport to govern itself as long as it is association based. When sport becomes business, it must abstain from the privileges enjoyed as an association' (Andersen 2015). ${ }^{10}$

\subsection{Output-Related Patterns of Legitimation: Effective Achievement of Regulatory Objectives}

Those advancing performance-related arguments in support of sport's right to regulate itself asserted that 'there was one thing sport could do better than the state and that was to mete out immediate, hard-hitting penalties on the [offending] athlete' (Vesper, 2014). Sports tribunals, it was pointed out, could suspend an athlete just on suspicion of an offence; normal courts could not (Kauerhof, 2007, p. 73). ${ }^{11}$ Furthermore, athletes who tested positive for illicit substances could be given a ban of up to four years by a sports tribunal, which was much more of a deterrent than the sorts of penalties that could be expected at the end of cumbersome legal proceedings in a criminal court (Spox.com, 2015). With these factors in mind, representatives of sports associations repeatedly argued that the introduction of criminal legislation would weaken sport's own regulatory authority: 'The system of sanctions provided for in sporting law would suffer a loss of legitimacy if the penalties imposed by sport differed completely from those imposed by the state' (Vesper, 2014; see also Hungermann, 2015). Echoing these concerns, a sceptical German Bar Association warned against succumbing to the illusion that the detection-rates for doping would be any better under the state and described the new German anti-doping legislation as no more than symbolic politics (Bouhs \& Kempe, 2015).

At the same time, performance-oriented observers who were critical of self-regulation maintained that sanc- tions could not be effective without input from the state. Thus, supporters of national anti-doping legislation, whilst not denying the ability of sports tribunals to deliver swift, appropriate, sports-specific, consistent (and therefore equitable) rulings, pointed out that such tribunals lacked the evidential reach of the courts. They highlighted sport's lack of appropriate investigative tools and argued that criminal legislation was needed not only for general preventative purposes but also to deal with repression (Krings, 2015). 'The punitive options open to sport should', they urged, 'be complemented by the more far-reaching tools available to the investigative authorities of the state....This is a question of 'effective parallel engagement, not of one side competing with the other' (Freitag, 2015). The legal powers and detection facilities of the state were needed in order, for example, to be able to summon witnesses, conduct searches, tap phones, and confiscate drugs (Haas, 2004). Again, only the state, it was argued, could ensure that those who had cheated were actually brought to book (Norddeutscher Rundfunk, 2015). An overall conclusion drawn from all this was that both institutions were needed-'sporting regulation and, as a last resort, for the really difficult cases, criminal justice' (Krings, 2015). ${ }^{12}$

The way in which the WADC focused on individual athletes as the addressees of regulation was identified as part of the reason why the Code had failed not only to halt the growth in the use of, and trade in, banned substances but also to counteract the increasing involvement of organized crime in this market. Again, whilst the WADC provided for the imposition of sanctions on athletes who breached its rules, it made no provision for the compensation of disadvantaged co-competitors. Selfregulation, it was conceded, could prevent and punish 'dirty victories' by imposing suspensions and voiding results for specific events where anti-doping rules were breached. Effective sanctioning of 'dirty money', by contrast, was felt not to be possible without the involvement of the state-the only actor that could reach beyond the immediate sporting sphere to protect or punish affected outsiders (Kauerhof, 2007, p. 75). Coaches, agents, and physiotherapists whose athletes had tested positive for banned substances were beyond WADA's punitory reach only national anti-doping laws had the power-as WADA president John Fahey put it - 'to catch the cheats behind the cheats' (Majendie, 2013). ${ }^{13}$

Athletes - the people directly affected by the actions of cheating fellow competitors-joined with sports officials in accusing sports federations of not taking the fight against doping seriously enough and called upon them to play a more active role in this area (Reinsch, 2015). Addressing allegations of systematic doping in Russian athletics, an independent commission chaired by former

\footnotetext{
10 In a similar vein, Michael Hershman, a former member of FIFA's Independent Governance Committee (IGC) argued that 'sport needs to be regulated and treated for what it is: big business' and that 'every single governing body in the sports world...needs to agree to modern standards of transparency and accountability' (Toman-Miller, 2015).

11 This naturally raises worries about rule-of-law deficits being a downside of greater effectiveness.

12 See also Engelmeier (2015)

13 See also Haas (2004).
} 
WADA president Richard Pound expressed similar criticism, accusing WADA of 'having been too soft on enforcing compliance with its code' (Rumsby, 2015; WADA, 2015). The state, it was argued, must step in to control negative externalities whose effects reached far beyond the sporting domain-into areas such as public health and the economic interests of those disadvantaged by others' use of banned substances. Even current WADA director-general David Howman conceded that the regulatory problem was 'getting too big for sport to manage' and made explicit reference to global organized crime. ${ }^{14}$ 'Unless we make something mandatory', he observed, people won't do it' (Gibson, 2013).

Although state involvement was considered a necessary condition for the improved achievement of sport's own regulatory objectives, the fact that the state could also be part of the problem did not pass unnoticed: the independent WADA report on doping in Russian athletics stated that it would be naïve in the extreme to conclude that activities on the scale discovered could have occurred without the explicit or tact approval of Russian governmental authorities' (WADA, 2015, p. 48).

\subsection{Input-Related Patterns of Legitimation}

\subsubsection{Protection of Individual Rights}

One of the major demands in relation to public regulation was that it should monitor private norm-setting and norm-enforcement for possible abuse. The same normative criteria, relating to fundamental rights and procedural requirements, were used to judge the structures and rulings of sporting bodies and the state-based elements of the lex sportiva. Apart from the invocation of the right to associational freedom and self-government, which was aimed at defending sporting autonomy (see 4.1.), most arguments based on the protection of fundamental rights and procedural requirements targeted weaknesses in private self-regulation and sought to bolster the case for public legislation. There was one interesting exception, however: the DOSB argued that, as part of the fundamental right to self-determination, even the right to selfdestructiveness must be preserved. If the state restricted this 'right to self-harm' by imposing, as it were, a duty to follow a healthy life-style, then this could not be confined to sporting activities: it must also apply, for example, to alcohol and tobacco consumption (Becker, 2015b). On these grounds, it was said, national anti-doping legislation constituted exceptional criminal legislation that could not be justified (Künast, 2015). Those in favour of the legal prohibition of doping were challenged to explain 'why top-level athletes should not have the same right as all other people involved in sport, or all other people in general, to put their health at risk' (Mutlu, 2015).

The view of organized athletes, however, was that autonomy had primarily been used as a shield behind which to 'remove the fundamental rights of athletes as profes- sional working people' (Schwab, 2015). In evidence, they cited the fact that, prior to any Olympic Games, the IOC, the various national sports associations, and all the individual athletes are required to give undertakings that, should relevant circumstances arise, they will not use any means of legal redress other than those provided 'in-house'. Sport's private arbitration system thus compels athletes to sign agreements with their respective national sporting associations waiving their basic civil right to seek redress from national courts. Fundamental rights and their violation also attracted public attention when the European Court of Justice dealt with a number of individual lawsuits against sporting associations. Thus, in what has come to be known as the Bosman Rulingunder which football players in the European Union may now change clubs at the end of their contract without a transfer-fee being paid-the court concluded that the abolition as between Member States of obstacles to freedom of movement for persons would be compromised if the abolition of State barriers could be neutralized by obstacles resulting from the exercise of their legal autonomy by associations or organizations not governed by public law' (ECJ, 1995).

Because of the monopoly status of sports associations, the allegedly voluntary nature of individual consent to a sporting association's rules is not regarded as a real counter to the imbalance between, on the one hand, the opportunities open to the regulatory subjects to influence the rules that apply to them and, on the other, the grave consequences of decisions made on the basis of those rules, or even simply of a refusal to submit oneself to the relevant regulatory regime. Against this background, lawyers have described the lex sportiva as a form of 'authoritarian rule by monopolistic associations' (Reuter, 1996, as cited by Röthel, 2007, p. 758).

\subsubsection{Rule of Law and Equal Treatment Before Courts}

The assurance of equal treatment before sports tribunals was repeatedly cited as proof of the legitimacy of sport's own procedures. Pointing to current 'harmonisation for all sports and all countries' and the 'huge achievement' this represented, WADA director-general David Howman warned against a shift to national anti-doping legislation. Such a move, he said, 'would result in athletes in different sports or from different countries receiving different bans for the same offences, and even worse athletes from the same sport receiving different penalties depending on the country they competed for' (Telegraph, 2012).

Given this gloomy prospect of piecemeal national solutions, duplicate competencies, and varying legal standards, the Court of Arbitration for Sport (CAS) was seen as the only mechanism offering international scope and consistency in the resolution of anti-doping disputes. The CAS itself pointed out that with involvement by national courts, 'the risk of contradictory decisions would [be]

\footnotetext{
14 Speaking of the UK, Howman stated: 'If you think the mafia and underworld aren't involved in this country in sport, you're in fairyland' (Gibson, 2013).
} 
higher with athletes being able to compete in certain countries but not in others' (CAS, 2015). ${ }^{15}$ The DOSB's Athletes' Commission argued along the same lines: 'Having standard judicial procedures for sport is the only way to ensure that all sportswomen and sportsmen, and all infringements of the rules, are treated equally' (DOSB, 2015). When it came to other matters, howevernamely, rule of law, impartiality, independence, and transparency-grave doubts were raised about the CAS. These issues loomed large, for example, in the case brought by German skater Claudia Pechstein against the International Skating Union. The Higher Regional Court in Munich, to which the skater had appealed, concluded that sports associations were abusing their 'market dominance' because they had major influence in determining who was appointed to the CAS's board of arbitrators (Becker, 2015b). National legislation was advocated as a necessary means of controlling the private abuse of regulatory authority-which, in the case just described, meant ensuring that the rule of law prevailed in regard to the neutrality of sports tribunals. An increased focus on the principle of the presumption of innocence was also broadly supported. Athletes' protection should be enhanced by making it a requirement that prosecutors prove possession of performance-enhancing substances for doping purposes (de Maizière, 2015). ${ }^{16}$

\subsubsection{Accountability Mechanisms}

Arguments relating to inadequate democratic procedure were voiced mainly in regard to the private elements of the lex sportiva. The poor extent to which the regulatory authority exercised by sports organizations was subject to oversight and control was regarded as denting the legitimacy of sporting self-regulation. It was pointed out that most of the 35 international Olympic sports federations lacked an institutional design that would "[allow] their constituents to monitor and sanction decision-making body members' (Geeraert, 2015, pp. 9-10). Transparency International, in its 2016 Global Corruption Report, described the corporate structures of sport as archaic and claimed that sports organizations had actually 'chosen not to adapt in order to protect certain self-interests, including high salaries, bonuses and virtually limitless tenures' (Transparency International, 2016, p. xix). ${ }^{17}$ From the perspective of athletes, 'sports are structured as cartels, they warrant not special treatment and protection but enhanced scrutiny and accountability' (Schwab, 2015).

Again, in the wake of the previously mentioned Pound report on Russian doping, the head of Australian athletics is reported to have pointed to the absence of a robust, overarching IAAF governance structure and clear lines of accountability at the International Association of Athletics Federations (IAFF), claiming that this had 'enabled practices that have compromised the integrity of the whole sport of athletics' (Sports Inquirer, 2016). Pound himself talked of 'a complete breakdown of governance structures and lack of accountability' at the IAAF and claimed the organization was guilty of 'an evident lack of political appetite...to confront Russia with the full extent of its known and suspected doping activities' (The National, 2016). It had, said Pound, failed to tackle the nepotism that had made possible one of the most corrupt regimes ever seen in sport (Rumsby, 2016). Criminologist Dieter Roessner suggests the prosecution of specific cases of doping by sports authorities is essentially a tactic to distract attention from a systemic problem by individualizing it (Bouhs \& Kempe, 2015).

\section{Conclusion}

Amidst reports that democratic sources of political legitimacy are undergoing a decline, this study tackles the issue by asking whether the emergence of private forms of regulation in the transnational sphere has brought with it a shift in the normative standards used to judge regulatory authority or whether the legitimation of private self-regulation and state-based regulation are grounded in similar values. Three ideal-type patterns of legitimation were tested for plausibility on the basis of a content analysis of actual controversies about the legitimacy of regulatory authority in the sporting domainspecifically, the hybrid governance-regime relating to the use of performance-enhancing substances in sports.

Comparison of patterns of legitimation for the public and private elements of the regime revealed that there was no systematic difference between the values on which the two kinds of elements were judged. Arguments drawing on democratic sources of political legitimacy were remarkably present in the debates about self-regulation in sport and were, in fact, utilized by both sides to justify their positions. The plausibility test did not support the notion that the spread of private selfregulation has resulted in a decline in the importance of input-related factors in legitimation. These include, for example, accountability, impartiality in regulatory proceedings, and the protection of fundamental rights such as the democratic right to self-determination and to the oversight and control of power.

Generalizations on the basis of a single-country, single-sector plausibility-test-albeit supplemented by anecdotal evidence from other sources-must, of course, be approached with care. A collation of insights from various case-studies could form the basis of a more systematic comparative investigation. These studies should include reviews of regulatory regimes that are not such ready candidates for politicization: one reason for the

\footnotetext{
15 See also de Maizière (2015).

16 The WADA report on systematic doping in Russia, released on 9 November 2015, also addressed 'major concerns about RUSADA's [Russian Anti-Doping Agency] functioning as an impartial institution' (WADA, 2015, p. 16). See also Bouhs and Kempe (2015).

17 See also Alvad (2016).
} 
wide range of patterns of legitimation proffered in the debates about the hybrid regime's private core may lie in the comprehensiveness of the political authority the regime has acquired and the legitimatory requirements that follow from this. Important additional insights could also be gained by taking possible cross-sector differences into account. Whether regulatory authority is wielded by a business corporation or by civil society, for example, is likely to be of some significance.

\section{Acknowledgments}

This article emerged from the collaboration of the Peace Research Institute Frankfurt and the Max Planck Institute for European Legal History in the Frankfurt Cluster of Excellence 'The Formation of Normative Orders'. The author wishes to thank all participating institutions for their support.

\section{Conflict of Interests}

The author declares no conflict of interests.

\section{References}

Abbott, K. W., \& Snidal, D. (2009). The governance triangle: Regulatory standards institutions and the shadow of the state. In W. Mattli \& N. Woods (Eds.), The politics of global regulation (pp. 44-88). Princeton, NJ: Princeton University Press.

Adolphsen, J., \& Kauerhof, R. (2013). Überfällige Sanktionierung oder unzulässige Einmischung? Legal Tribune Online. Retrieved from http://www.Ito.de/ recht/hintergruende/h/anti-doping-gesetz-pro-contra

Alvad, S. (2016). Report examines corruption in sport. Playthegame. Retrieved from http://www.playthe game.org/news/news-articles/2016/0148_report-ex amines-corruption-in-sport

Andersen, J. S. (2015). Comment. Playthegame. Retrieved from http://www.playthegame.org/news/ comments/2015/021_the-year-that-killed-the-auto nomy-of-sport

Becker, C. (2015a). Attacke vom DOSB auf die Regierung. Faz.net. Retrieved from http://www.faz.net/aktuell/ sport/sportpolitik/anti-doping-gesetz-dosb-attackie rt-regierung-13419045.html

Becker, C. (2015b). Versuchte Kernschmelze. Faz.net. Retrieved from http://www.faz.net/aktuell/sport/sport politik/anti-doping-gesetz-dosb-widerspricht-regieru ng-13419049.html

Benz, A., \& Papadopoulos, Y. (2006). Introduction. Governance and democracy: Concepts and key issues. In A. Benz \& Y. Papadopoulos (Eds.), Governance and democracy (pp. 1-26). London and New York, NY: Routledge.

Bernstein, S. (2011). Legitimacy in intergovernmental and non-state global governance. Review of International Political Economy, 18(1), 17-51.
Bernstein, S., \& Cashore, B. (2007). Can non-state global governance be legitimate? An analytical framework. Regulation and Governance, 1(4), 347-371.

Bodansky, D. (2013). Legitimacy in international law and international relations. In J. L. Dunoff \& M. A. Pollack (Eds.), Interdisciplinary perspectives on international law and international relations: The state of the art (pp. 321-342). Cambridge: Cambridge University Press.

Boerzel, T., \& Risse, T. (2005). Public-private partnerships: Effective and legitimate tools of international governance? In E. Grande \& L. W. Pauly (Eds.), Complex sovereignty. Reconstituting political authority in the twenty-first century (pp. 195-216). Toronto: University of Toronto Press.

Bouhs, D., \& Kempe, R. (2015). Hoffnung auf einen sauberen Sport. Deutschlandfunk. Retrieved from http://www.deutschlandfunk.de/anti-doping-gesetz -hoffnung-auf-einen-sauberen-sport.724.de.html?dr am:article_id=340958

Cashore, B. (2002). Legitimacy and the privatization of environmental governance: How non state marketdriven (NSMD) governance systems gain rule making authority. Governance, 15(4), 503-529.

Coni-Zimmer, M., Wolf, K. D., \& Collin, P. (2017). Editorial to the issue on legitimization of private and public regulation: Past and present. Politics and Governance, 5(1), 1-5.

Council of Europe. (1989). Anti-doping convention. Retrieved from http://conventions.coe.int/Treaty/en/ Treaties/Html/135.htm

Court of Arbitration for Sport. (2015). Statement of the Court of Arbitration for Sport (CAS) on the decision made by the Oberlandesgericht München in the case between Claudia Pechstein and the International Skating Union (ISU). Retrieved from http:// www.tas-cas.org/fileadmin/user_upload/CAS_state ment_ENGLISH.pdf

Cutler, A. C., Haufler, V., \& Porter, T. (Eds.). (1999). Private authority and international affairs. Albany, NY: SUNY Press.

de Maizière, T. (2015). Dieser Gesetzentwurf ist kurz, klar, hart und wirksam. Cducsu. Retrieved from https://www.cducsu.de/themen/innen-recht-sportund-ehrenamt/dieser-gesetzentwurf-ist-kurz-klar-ha rt-und-wirksam

Dingwerth, K. (2007). The new transnationalism: Transnational governance and democratic legitimacy. Basingstoke: Palgrave Macmillan.

Deutscher Olympischer Sportbund. (2015). Declaration of the DOSB athletes' commission. Retrieved from https://www.dosb.de/de/leistungssport/anti-doping/ news/detail/news/dosb_athletenkommission_zum_ anti_doping_gesetz

Engelmeier, M. (2015). Es wird ungemütlich für Doperdas Anti-Doping-Gesetz stärkt den Sport. Retrieved from http://www.michaela-engelmeier.de/archiv/eswird-ungemuetlich-fuer-doper-das-anti-doping-gese tz-staerkt-den-sport.html 
European Court of Justice. (1995). Judgment of the Court of 15 December 1995. Case C-415/93. European Court Reports. Retrieved from http://eur-lex.europa. eu/legal-content/EN/TXT/HTML/?isOldUri=true\&uri= CELEX:61993CJ0415

Financial Times. (2014). International sport should not be a law unto itself. Financial Times. Retrieved from http://www.ft.com/cms/s/0/3a78e04c-7baa-11e4-a 695-00144feabdc0.html\#axzz42VtMU9Mb

Flohr, A., Rieth, L., Schwindenhammer, S., \& Wolf, K. D. (2010). The role of business in global governance. Basingstoke: Palgrave Macmillan.

Freitag, D. (2015). Interview: Dagmar Freitag begrüßt das Gesetz gegen Doping. Deutscher Bundestag. Retrieved from http://www.bundestag.de/dokumen te/textarchiv/2015/kw47-interview-freitag/395596

Geeraert, A. (2015). Sports governance observer 2015. The legitimacy crisis in international sports governance (Report). Copenhagen: Danish Institute for Sports Studies.

Gibson, O. (2013). Drugs in sport: WADA says doping and organised crime 'too big to manage'. The Guardian. Retrieved from https://www.theguardian.com/sport /2013/feb/15/drugs-wada-organised-crime

Gutmann, A. (Ed.). (1998). Freedom of association. Princeton, NJ: Princeton University Press.

Haas, U. (2004). Effektive Dopingbekämpfung ist ohne Staat nicht möglich. Faz.net. Retrieved from http://www.faz.net/aktuell/sport/sportpolitik/doping gesetzgebung-effektive-dopingbekaempfung-ist-ohne -staat-nicht-moeglich-1146943.html

Hall, R. B., \& Biersteker, T. J. (2002). The emergence of private authority in the international system. In R. B. Hall \& T. J. Biersteker (Eds.), The emergence of private authority in global governance (pp. 3-22). Cambridge: Cambridge University Press.

Held, D., \& Koenig-Archibugi, M. (2005). Global governance and public accountability. Oxford: Blackwell Publishing.

Héritier, A. (Ed.). (2002). Common goods. Reinventing European and international governance. Lanham, MD: Rowman and Littlefield.

Héritier, A., \& Lehmkuhl, D. (2008). Introduction: The shadow of hierarchy and new modes of governance. Journal of Public Policy, 28(1), 1-17.

Hungermann, J. (2015). Neues Antidopinggesetz sieht Haftstrafen vor. Welt. Retrieved from http://www. welt.de/sport/article138747683/Neues-Antidoping gesetz-sieht-Haftstrafen-vor.html

Kauerhof, R. (2007). Ein Anti-Doping-Gesetz als Garant für den sauberen Sport? HRRS. Onlinezeitschrift für Höchstrichterliche Rechtsprechung im Strafrecht, 2(8), 71-75. Retrieved from http://hrr-strafrecht.de

Keohane, R. O., \& Nye, J. S. (2003). Redefining accountability for global governance. In H. Kahler \& D. A. Lake (Eds.), Globalizing authority (pp. 386-411). Princeton, NJ: Princeton University Press.

Kooiman, J. (2000). Societal governance: Levels, modes, and orders of social-political interaction. In J. Pierre (Ed.), Debating governance (pp. 138-164). Oxford: Oxford University Press.

Krahmann, E. (2017). Legitimizing private actors in global governance: From performance to performativity. Politics and Governance, 5(1), 54-62.

Krings, G. (2015). Betrug und Unfairness wollen wir im Sport nicht. Retrieved from https://www.cducsu.de/ themen/innen-recht-sport-und-ehrenamt/betrug-und -unfairness-wollen-wir-im-sport-nicht

Künast, R. (2015). Doping im Sport. Gruene-bundestag. Retrieved from https://www.gruene-bundestag.de/ ?id $=4395524$

Majendie, M. (2013). Exclusive: Wada chief John Fahey to target the cheats behind the drug cheats. Independent. Retrieved from http://www. independent.co.uk/sport/general/athletics/exclusive -wada-chief-john-fahey-to-target-the-cheats-behindthe-drug-cheats-8729058.html

Mayntz, R. (2002). Common goods and governance. In A. Héritier (Ed.), Common goods: Reinventing European and international governance (pp. 15-27). Lanham, MD: Rowman \& Littlefield.

Michael, L. (2005). Private Standardsetter und demokratisch legitimierte Rechtsetzung. In H. Bauer, P. M. Huber, \& K.-P. Sommermann (Eds.), Demokratie in Europa (pp. 431-456). Tübingen: Mohr Siebeck.

Mutlu, Ö. (2015). Doping im Sport. Gruene-bundestag. Retrieved from https://www.gruene-bundestag.de/ ?id $=4395523$

Norddeutscher Rundfunk. (2015). Maas setzt grosse Hoffnung in Anti-Doping-Gesetz. NDR.de. Retrieved from http://www.ndr.de/sport/mehr_sport/Maassetzt-grosse-Hoffnung-in-Anti-Doping-Gesetz, heiko maas108.html

Papadopoulos, Y. (2010). Accountability and multi-level governance: More accountability, less democracy? West European Politics, 33(5), 1030-1049.

Pattberg, P. (2005). The Forest Stewardship Council: Risk and potential of private forest governance. Journal of Environment Development, 14(3), 356-374.

Pattberg, P. (2006). Private governance and the South: Lessons from global forest politics. Third World Quarterly, 27(4), 579-593.

Pierre, J. (2000). (Ed.). Debating governance (pp. 138164). Oxford: Oxford University Press.

Pollitt, C., \& Bouckaert, G. (2000). Public management reform: A comparative analysis. Oxford: Oxford University Press.

Reinsch. M. (2015). Cookson: 'Strafrecht für Doper eine gute Idee'. Faz.net. Retrieved from http://www. faz.net/aktuell/sport/sportpolitik/doping/anti-doping -gesetz-cookson-strafrecht-fuer-doper-eine-gute-idee $-13572097 . \mathrm{html}$

Reuter, D. (1996). Das selbstgeschaffene Recht des internationalen Sports im Konflikt mit dem Geltungsanspruch des nationalen Rechts. Deutsche Zeitschrift für Wirtschafts- und Insolvenzrecht, 6(1), 1-9. 
Ronit, K., \& Schneider, V. (2000). Private organizations and their contribution to problem-solving in the global arena. In K. Ronit \& V. Schneider (Eds.), Private organizations in global politics (pp. 1-33). London: Routledge.

Röthel, A. (2007). Lex mercatoria, lex sportiva, lex technica-Private Rechtsetzung jenseits des Nationalstaates? JuristenZeitung, 62(15/16), 755-763.

Rumsby, B. (2015). Russia cannot send athletics team to Rio Olympic Games if it fails to fix drugs scandal, says Wada chief. Telegraph. Retrieved from http:// www.telegraph.co.uk/sport/othersports/athletics/1 1997521/Russia-cannot-send-athletics-team-to-RioOlympic-Games-if-it-fails-to-fix-drugs-scandal-saysWada-chief.html

Rumsby, B. (2016). Lord Coe admits to failings as doping scandal deepens following Wada doping report. Telegraph. Retrieved from http://www.telegraph.co.uk/ sport/othersports/athletics/12099794/Lord-Coe-un der-intense-pressure-after-damning-WADA-dopingreport.html

Scharpf, F. (1999). Governing in Europe: Effective and democratic? Oxford and New York, NY: Oxford University Press.

Schiedermair, S. (2012). Der Schutz des Privaten im Völkerrecht. Tübingen: Mohr Siebeck.

Scholte, J. A. (2011). Building global democracy? Civil society and accountable global governance. Cambridge: Cambridge University Press.

Schwab. B. (2015). Organised athletes: A critical voice in sports governance. Retrieved from http:// blog.transparency.org/2015/09/11/organised-athle tes-a-critical-voice-in-sports-governance

Siekmann, R. C. R. (2012). Anti-doping law in sport: The hybrid character of WADA and the human rights of athletes in doping cases (proportionality principle). In R. C. R. Siekmann (Ed.), Introduction to international and European sports law (pp. 313-333). The Hague: Springer.

Simmerl, G., \& Zuern, M. (2016). Internationale Autorität. Zeitschrift für Internationale Beziehungen, 23(1), 38-70.

Sports Inquirer. (2016). Athletics: Australia backs embattled Coe after WADA report. Retrieved from http:// sports.inquirer.net/203564/athletics-australia-backs -embattled-coe-after-wada-report

Spox.com. (2015). Gegenwind für Anti-DopingGesetz. Retrieved from http://www.spox.com/de/ sport/mehrsport/1506/News/anti-doping-gesetz-ge genwind-bundestag-robert-harting.html

Telegraph. (2012). London 2012 Olympics: World AntiDoping Agency hit back after Daley Thompson attack. Telegraph. Retrieved from http://www. telegraph.co.uk/sport/olympics/news/9123182/Lon don-2012-Olympics-World-Anti-Doping-Agency-hitback-after-Daley-Thompson-attack.html

The National. (2016). Corruption 'embedded' at IAAF, claims Wada report. The National. Retrieved from http://www.thenational.ae/sport/other/corruptionembedded-at-iaaf-claims-wada-report

Toman-Miller, M. A. (2015). U.S. soccer official says he saw no FIFA corruption but felt growing 'discomfort'. Los Angeles Times. Retrieved from http://www.la times.com/nation/la-na-us-soccer-congress-201507 15-story.html

Transparency International. (2016). Global corruption report. Sport. Retrieved from http://www.transparency. org/news/feature/sport_integrity

UNESCO. (2005, October 19). International Convention against doping in sport 2005. UNESCO. Retrieved from http://portal.unesco.org/en/ev.php-URL_ID $=3$ 1037\&URL_DO=DO_TOPIC\&URL_SECTION=201.html

Vesper, M. (2014). Für hartes Anti-Doping-Gesetz und durchgreifende Sportgerichte. DOSB. Retrieved from http://www.dosb.de/de/leistungssport/antidoping/news/detail/news/fuer_hartes_anti_doping _gesetz_und_durchgreifende_sportgerichte

Wolf, K. D. (2002). Contextualizing normative standards for legitimate governance beyond the state. In J. R. Grote \& B. Gbikpi (Eds.), Participatory governance (pp. 35-50). Opladen: Leske \& Budrich.

Wolf, K. D. (2006). Private actors and the legitimacy of governance beyond the state: Conceptional outlines and empirical explorations. In A. Benz \& Y. Papadopoulos (Eds.), Governance and democracy (pp. 200-227). London and New York, NY: Routledge.

Wolf, K. D. (2008). Emerging patterns of global governance: The new interplay between the state, business and civil society. In A. G. Scherer \& G. Palazzo (Eds.), Handbook of research on global corporate citizenship (pp. 225-248). Cheltenham: Edward Elgar.

Wolf, K. D. (2014). The non-existence of private selfregulation in the transnational sphere and its implications for the responsibility to procure legitimacy: The case of the lex sportiva. Global Constitutionalism, 3(3), 275-309.

Wolff, J., \& Zimmermann, L. (2016). Between banyans and battle scenes: Liberal norms, contestation, and the limits of critique. Review of International Studies, 42(3), 513-534.

World Anti-Doping Agency. (2014). World anti-doping code 2015. Retrieved from https://www.wada-ama. org/sites/default/files/resources/files/wada-2015-w orld-anti-doping-code.pdf

Word Anti-Doping Agency. (2015, November 9). The Independent Commission report\#1. Final report. Retrieved from https://www.documentcloud.org/docu ments/2509901-wada-independent-commission-rep ort-1-en.html

World Conference on Doping in Sport. (2003). Copenhagen Declaration on Anti-Doping in sport 2003. Retrieved from https://www.wada-ama.org/en/resources/world -anti-doping-program/copenhagen-declaration

Zagzebski, L. (2012). Epistemic authority: A theory of trust, authority, and autonomy in belief. Oxford: Oxford University Press. 
Zuern, M. (2011). Perspektiven des demokratischen Regierens und die Rolle der Politikwissenschaft im 21. Jahrhundert. Politische Vierteljahresschrift, 52(4), 603-635.

Zuern, M. (2012). Globalization and global governance. In W. Carlsnaes, T. Risse, \& B. A. Simmons (Eds.), Handbook of international relations (pp. 401-425). London: Sage.
Zuern, M. (2014). The politicization of world politics and its effects: Eight propositions. European Political Science Review, 6(1), 47-71.

Zuern, M., Binder, M., \& Ecker-Ehrhardt, M. (2012). International authority and its politicization. International Theory, 4(1), 69-106.

\section{About the Author}

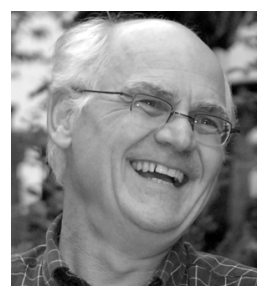

Klaus Dieter Wolf is Professor of International Relations at Technische Universität Darmstadt, Germany, and was formerly Executive Director of the Peace Research Institute Frankfurt. He has written extensively on private actors in global governance and on international institutions. He is one of the Principal Investigators of the Frankfurt Cluster of Excellence 'Normative Orders'. His publications include The Role of Business in Global Governance (Palgrave Macmillan, 2010, co-author), Global Crime Governance (Palgrave Macmillan, 2013, co-editor), and Resistance and Change in World Politics (Palgrave Macmillan, 2017, co-editor). 